J. Clin. Chem. Clin. Biochem.

Vol. 16, 1978, pp. 631-635

\title{
Rapid Determination of Proteins in Serum and Cerebrospinal Fluid by Laser-Nephelometry
}

\author{
By Gisela Schliep and K. Felgenhauer
}

Neuropsychiatrische Forschungsabteilung der Universitäts-Nervenklinik Köln

(Received March 13/July 17, 1978)

\section{Dedicated to Professor Dr. A. Stammler on the occasion of his 60 th birthday}

Summary: The Laser-nephelometric technique is characterized by its easy handling, accuracy, good reproducibility and especially by the short time in which reliable results are available. A very good correlation was found between the results obtained by the electroimmunoassay and those obtained by Laser-nephelometry. In both techniques $\alpha_{2}$ macroglobulin is the largest serum protein that can be determined in normal unconcentrated cerebrospinal fluid (CSF). This is of diagnostic significance, since the serum/CSF ratios of both albumin and $\alpha_{2}$-macroglobulin are used as a parameter for the blood-CSF barrier condition.

\section{Schnelle Bestimmung von Proteinen im Serum und Liquor cerebrospinalis mit der Laser-Nephelometrie}

Zusammenfassung: Die Laser-Nephelometrie zeichnet sich durch einfache Handhabung, Genauigkeit und gute Reproduzierbarkeit aus. Der größte Vorteil im Vergleich zu konventionellen Methoden liegt in der Zeitersparnis. Die Korrelation der Ergebnisse, die mit der Laser-Nephelometrie und der elektroimmunologischen Proteinbestimmung gewonnen wurden, war sehr gut. Das größte Serumprotein, das mit beiden Techniken in normalem unkonzentrierten Liquor bestimmt werden kann, ist das $\alpha_{2}$-Makroglobulin. Dies ist von diagnostischer Bedeutung, da der Proteingradient der Serum-Liquor-Quotienten von Albumin and $\alpha_{2}$-Makroglobulin als Parameter der Blut-Liquor-Schrankenfunktion dient.

\section{Introduction}

In recent years the quantitative determination of single proteins in biological fluids has become a diagnostic tool of great significance. Using these methods, even those proteins previously considered to be extraneous in normal cerebrospinal fluid e. g. fibrinogen, IgM and $\beta$-lipoprotein (1), can be detected.

Although the electroimmunoassay (2) was found to be suitable in routine work (3) the application of Lasernephelometry or Laser light scattering immunoassay both terms are used synonymously - is a further progress in laboratory diagnostics. This assay is based upon the formation of complexes between a particular antigen and its specific antibody, that can be measured by nephelometry, The major advantage of this technique is the time saved in comparison with other methods.

\section{Material and Methods}

In the serum and cerebrospinal fluid of 50 patients suffering from a variety of neurological diseasses and psychiatric disorders, the determination of albumin, $\operatorname{Ig} G, \operatorname{IgA}$ and $\alpha_{2}$-macroglobulin by the routine electroimmunoassay $(2,3)$ were compared with the re- sults obtained by Laser light scattering immunoassay. Since a good correlation was found between both immunological techniques (see page 632) in routine work, the electroimmunoassay was replaced by the Laser light scattering immunoassay. These four proteins were determined in specimens from 500 patients (both inand out-patients) between June and December 1977 in our hospital, using only Laser-nephelometry. All cerebrospinal fluid samples were free of erythrocytes. The total protein content of cerebrospinal fluid was determined according to Lowry et al. (4). In 200 of these 500 patients showing an increased total protein level of cerebrospinal fluid (above $600 \mathrm{mg} / \mathrm{l}$ ), the IgM and $\beta$ lipoprotein were measured additionally by Laser light scattering immunoassay in both serum and cerebrospinal fluid.

Those samples investigated by both techniques were handled as described elsewhere for the electroimmunoassay (3).

All determinations of proteins were made with the Laser-Nephelometer (Behring Institut, D355 Marburg, F. R. G.) and special plastic cuvettes (W. S. Sarstedt, Supplied by the Behring

Institut) were used. Laser nephelometric (LN)-tested antisera were applied. With the exception of $\beta$-lipoprotein, which was measured with $\beta$-lipoprotein reference serum, laser nephelometry reference serum was used. Both antisera and reference sera were obtained from the Behring Institut.

Prior to each assay the antiserum was centrifuged for 5 minutes at $2000 \mathrm{~g}$. The turbidity of 20 per cent antiserum, diluted with normal saline did not exceed 0.3 Volt at the output of the nephelometer. The patients' sera and cerebrospinal fluids as well as the reference sera were diluted with normal saline to yield postreactive turbidities, which corresponded to 0.2 to 8.0 Volt at the output of the nephelometer. 
The following dilution series were used for the standard curves: Albumin $=1: 2000$ to $1: 20000, \operatorname{IgG}=1: 300$ to $1: 6000, \operatorname{IgA}=$ $1: 100$ to $1: 1000, \alpha_{2}$-macroglobulin and $\beta$-lipoprotein $=1: 50$ to $1: 1000, \operatorname{lgM}=1: 25$ to $1: 400$.

The patients' sera were diluted as follows:

$\operatorname{IgA}, \operatorname{IgM}, \alpha_{2}$-macroglobulin, $\beta$-lipoprotein $=1: 201, \operatorname{IgG}=1: 1005$, Albumin $=1: 4020$.

Cerebrospinal fluid was centrifuged before investigation to remove any light scattering components. The dilution factors for cerebrospinal fluid were chosen according to its total protein content (tab. 1).

Tab. 1. Dilution factors of cerebrospinal fluid found empirically for the standard assay according to the total protein content of cerebrospinal fluid.

\begin{tabular}{lrrll}
\hline $\begin{array}{l}\text { Total Protein } \\
(\mathrm{mg} / \mathrm{l})\end{array}$ & Albumin & IgG & $\begin{array}{l}\text { IgA } \\
\alpha_{2} \text {-macro- } \\
\text { globulin }\end{array}$ & $\begin{array}{l}\text { IgM } \\
\beta \text {-lipoprotein }\end{array}$ \\
\hline below 300 & 20 & 2 & undiluted & undeterminable \\
$300-600$ & 50 & 5 & undiluted & $\begin{array}{l}\text { undeterminable } \\
\text { undiluted }\end{array}$ \\
$600-1000$ & 100 & 10 & undiluted & undiluted \\
$1000-2000$ & 200 & 20 & 2 & 2 \\
$2000-3000$ & 300 & 30 & 4 & 3 \\
$3000-5000$ & 500 & 50 & 5 & 5 \\
$5000-10000$ & 700 & 70 & 10 & 10 \\
beyond 10000 & 1000 & 100 & 20 & \\
\hline
\end{tabular}

\section{Standard assay}

To $0.1 \mathrm{ml}$ sample add

$0.16 \mathrm{ml}$ normal saline.

Read and note blank values, which should not exceed 0.3 Volt at the output of the nephelometer. Defective cuvettes are replaced. Add $0.04 \mathrm{ml}$ antiserum. Mix gently, air bubbles must be avoided. Cover the cuvettes to keep off dust particles. Incubate for one hour at room temperature. Read results and subtract the blank values of the samples. For final evaluation construct standard curves by plotting the intensities of the light scattering effect,

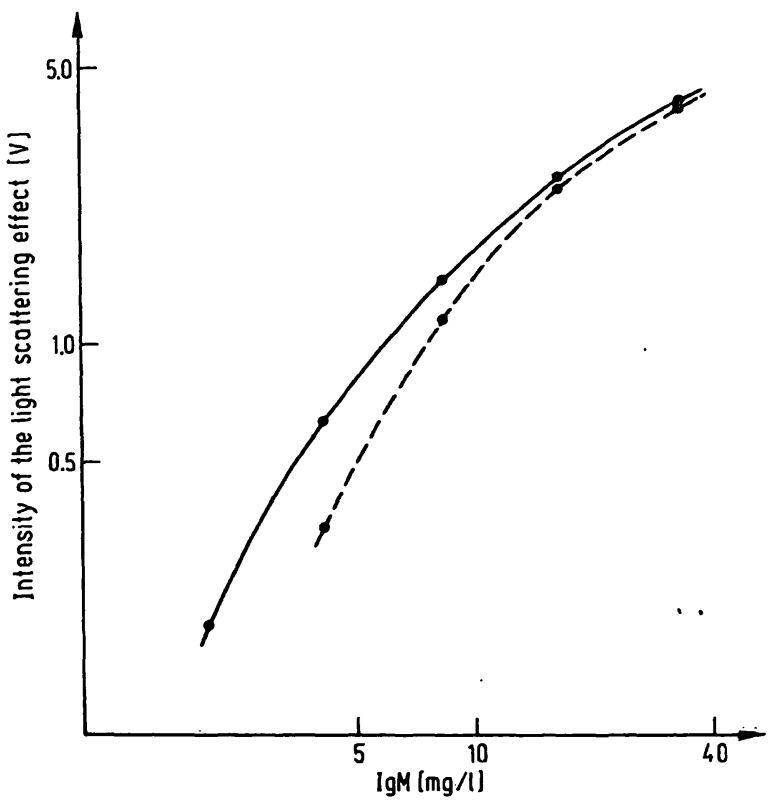

Fig. 1. Reference curves for the determination of IgM after one hour (broken line) and after two hours (drawn line) incubation time. measured in volts at the output of the nephelometer, against the concentration of the reference sera in $\mathrm{mg} / \mathrm{l}$ in a double logarithmic scale.

If the sera are taken from a fasting patient the blank turbidity is sufficiently low to omit clearing by Frigen as proposed by the manufacturer (5).

The turbidity resulting from the formation of antigen-antibody complexes should not exceed 8 Volt at the output of the nephelometer. Above a critical antigen level, the antigen-antibody complexes descend to the bottom of the cuvette, apparently due to the formation of aggregates during the incubation time of one hour. If the voltage increment is lower than $0.2 \mathrm{~V}$ at the output of the nephelometer the incubation time is prolonged for another hour. The threshold of detection for cerebrospinal fluid proteins can be increased by prolongation of the incubation time (fig. 1) or replacement of saline by cerebrospinal fluid.

The addition of polyethylene glycol $\left(\mathrm{M}_{\mathrm{r}} 6000\right)$, however, as proposed by Lizana \& Hellsing (6) did not enhance the sensitivity for the determination of cerebrospinal fluid proteins. But it can decrease the antigen-antibody reaction time by a factor of 10 to $15(6,7)$.

\section{Results}

The following detection limits have been found with $0.26 \mathrm{ml}$ native cerebrospinal fluid in the standard assay (saline omitted) and an incubation time of two hours:

$\alpha_{2}$-macroglobulin $=1 \mathrm{mg} / 1, \operatorname{lgA}=1.2 \mathrm{mg} / 1$, IgM $=0.8 \mathrm{mg} / \mathrm{l}, \beta$-lipoprotein $=2.6 \mathrm{mg} / 1$.

The normal levels of IgM and $\beta$-lipoprotein could not be determined in unconcentrated cerebrospinal fluid.

There was a good correlation (tab. 2 and fig. 2) between the values of albumin, IgG, IgA and $\alpha_{2}$-macroglobulin in both serum and cerebrospinal fluid of those 50 patients that were investigated by both techniques, i. e. the electroimmunoassay and the Laser light scattering immunoassay. The concentration range in which both techniques could be applied and the day-to-day reproducibility found by Laser-nephelometry are summarized in table 2 .

The Laser light scattering immunoassay was performed on the cerebrospinal fluid (with normal cell count and normal protein content) from 25 patients between the 3rd and 7th decade of life, who were suffering from a psychosis - both schizophrenia and cyclothymia - or a neurosis. This cerebrospinal fluid was taken for differential diagnostic purposes. The further course of these cases did not reveal a somatic disorder and conventional laboratory tests were normal. As the concentration of serumderived proteins only depends on the actual barrier function, the serum/cerebrospinal fluid ratios of both albumin and $\alpha_{2}$-macroglobulin from these patients served to establish the lower limit of the normal barrier condition. As expected from the good correlation (tab. 2 and fig. 2) between both techniques no substantial difference was observed between these data and those obtained for the lower limit of the normal barrier state by the electroimmunoassay (8). Serum/cerebrospinal fluid ratios lower than 160 for albumin and lower than 650 for $\alpha_{2}$ - 
Tab. 2. Coefficient of correlation between the electroimmunoassay and the Laser light scattering immunoassay for proteins determined in serum and cerebrospinal fluid and day-to-day reproducibility found by Laser light scattering immunoassay.

\begin{tabular}{|c|c|c|c|c|c|c|}
\hline \multirow[t]{2}{*}{ Determined protein } & \multicolumn{2}{|c|}{$\begin{array}{l}\text { Coefficient of } \\
\text { correlation }\end{array}$} & \multicolumn{2}{|c|}{$\begin{array}{l}\text { Concentration range in which } \\
\text { both techniques could be applied }\end{array}$} & \multicolumn{2}{|c|}{$\begin{array}{l}\text { Day-to-day reproducibility } \\
\text { CV }(\%)\end{array}$} \\
\hline & serum & CSF & $\operatorname{serum}(g / 1)$ & $\mathrm{CSF}(\mathrm{mg} / \mathrm{l})$ & serum & CSF \\
\hline $\begin{array}{l}\text { Albumin } \\
\text { IgG } \\
\text { IgA } \\
\alpha_{2} \text {-macroglobulin }\end{array}$ & $\begin{array}{l}0.96 \\
0.97 \\
0.95 \\
0.98\end{array}$ & $\begin{array}{l}0.98 \\
0.95 \\
0.99 \\
0.98\end{array}$ & $\begin{array}{r}33.0-50.0 \\
4.7-14.4 \\
0.8-3.2 \\
0.9-4.7\end{array}$ & $\begin{array}{r}50.0-450.0 \\
6.3-140.0 \\
1.2-16.0 \\
1.2-20.0\end{array}$ & $\begin{array}{l}6.3 \\
5.6 \\
1.8 \\
1.9\end{array}$ & $\begin{array}{l}5.6 \\
3.2 \\
2.4 \\
1.3\end{array}$ \\
\hline
\end{tabular}

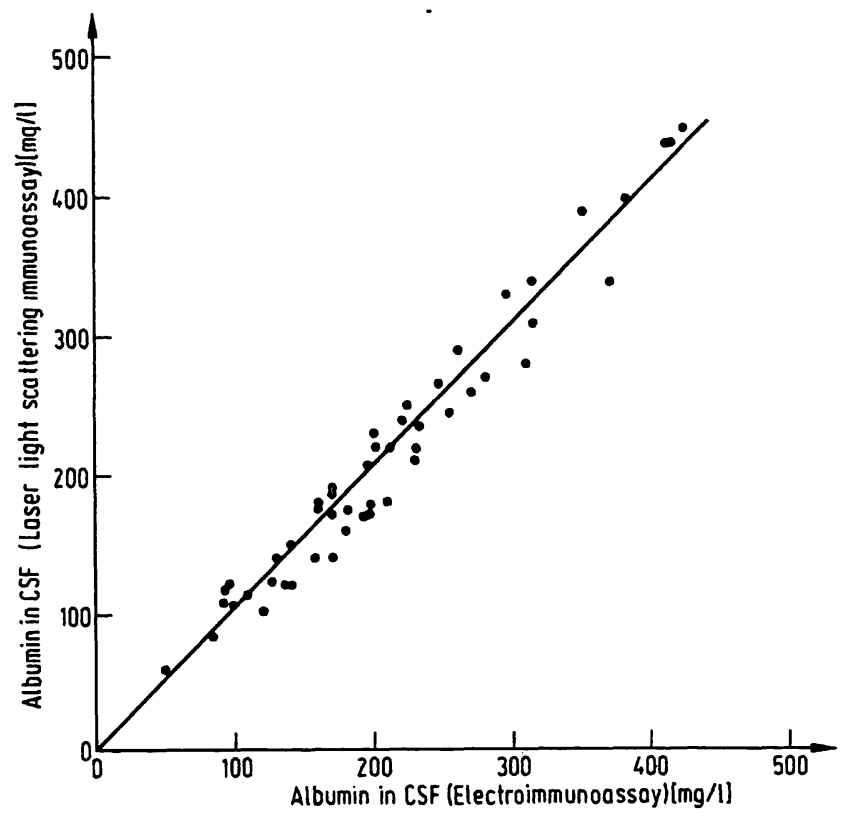

Fig. 2. Correlation between the Laser light scattering immunoassay and the electroimmunoassay demonstrated for the albumin levels in cerebrospinal fluid. The overall correlation coefficient is $\mathrm{r}=0.98$ (see tab. 2).

macroglobulin indicate a disturbance of the blood-cerebrospinal fluid barrier.

The serum/cerebrospinal fluid protein ratios determined for the remaining 475 patients suffering from a variety of neurological diseases and psychiatric disorders generally confirmed those results found with the electroimmunoassay (3). This was true of both disease groups i.e. those characterized by "pure" barrier disturbances and those inflammatory processes showing a local syn thesis of immunoglobulins.

\section{Discussion}

The speed with which reliable results are obtained, the easy handling, and the accuracy and reproducibility of Laser light scattering immunoassay will favour the application of this new technique in many clinical laboratories. The values obtained correlate well with those obtained by other immunological techniques, e.g. the radial im- munodiffusion (9) as reported by Sieber \& Gross (10), Pflughaupt (11), Pflughaupt et al. (12) and Conrad et al. (13). We found a good correlation (tab. 2 and fig. 2) between the results from the electroimmunoassay and those found by the Laser-nephelometry. The sensitivity of the electroimmunoassay and the Laser light scattering immunoassay is identical for cerebrospinal fluid proteins. The day-to-day reproducibility (tab. 2) found with the Laser nephelometry corresponds to results described for the electroimmunoassay (14). The major disadvantage of both conventional techniques, i.e. radial immunodiffusion and electroimmunoassay, is the time required. With radial immunodiffusion, results are not available earlier than 24 hours after starting the assay. For large proteins even a longer diffusion time has been recommended. Although results can be obtained more rapidly with the electroimmunoassay the carbamylation procedure necessary for the determination of both $\operatorname{IgG}$ and $\operatorname{IgM}(15,16)$ is time consuming. On the other hand the Laser light scattering immunoassay is more expensive, because it uses a larger amount of antiserum. If the amount of antiserum as proposed by the manufacturer is used (5), the consumption of antiserum is fourfold greater than for the electroimmunoassay. It is, however, possible to reduce this recommended quantity of antiserum by 25 or even 50 per cent per test. These costs are well compensated by the saving of time. Results from the Laser light scattering immunoassay are received within 2 and 3 hours after obtaining the sample, whereas the determination of proteins by the electroimmunoassay requires nearly 24 hours especially for high-molecular proteins. Moreover the Behring Laser-Nephelometer can be connected with a computer to speed up the procedure. Further mechanisation concerning the pipetting and dilution of samples is in preparation by the manufacturer (5).

The blank value determination was performed according to Richterich (17). This author has recommended that the sample blank should be prepared with all reagents, but with omission of the substance under test. This is a general recommendation for all biochemical assays depending on the measurement of light absorption, fluorescent emission or light scattering. Similar blank value determinations were performed by Killingworth \& Savory (18), Ritchie et al. (19) and Shenkin et al. (20). 
The major advantage of the polyethylene glycol addition is the acceleration of the antigen-antibody reaction $(6,7)$. This acceleration is useful in an automated system, but unnecessary under manual conditions. A prolongation of the incubation time up to two hours is useful for biological fluids poor in proteins.

The question arises as to which proteins should be determined in both serum and cerebrospinal fluid under routine conditions in a neurological and psychiatric hospital. The evaluation of the blood-cerebrospinal fluid barrier by serum/cerebrospinal fluid concentration ratios of both albumin and $\alpha_{2}$-macroglobulin is a more sensitive criterion than the determination of the total protein content (3). Slightly decreased serum/cerebrospinal fluid ratios of these two proteins may reveal a barrier disturbance although the total protein content remains in a normal range. But the determination of the total protein content in cerebrospinal fluid is a reliable screening test to decide which dilution factor is optimal for further investigations. In this way, unnecessary Laser nephelometric measurements can be prevented.

The applied barrier concept has proved to be a reliable criterion for deciding whether raised immunoglobulin levels are the result of passive transfer or of local synthesis within the nervous system. Under normal conditions the immunoglobulins are subject to the same principle of transfer from serum into the cerebrospinal fluid compartment as are the barrier markers albumin and $\alpha_{2}$ macroglobulin. The same is true of "pure" barrier disturbances, whereas a great deviation of the serum/cerebrospinal fluid immunoglobulin ratios occurs in cases with a local immunoglobulin synthesis. Delpech \& Lichtblau (21) found a correlation between the cerebrospinal fluid/serum ratios of both albumin and IgG. In cases with a disturbed blood-cerebrospinal fluid barrier both ratios increase, whereas in subjects with an IgG-production a significant deviation of the cerebrospinal fluid/serum IgG ratios appears. Their results have been confirmed by Ganrot \& Laurell (22) and Eickhoff et al. (23).

The rational of this coefficient proposed by Delpech \& Lichtblau (21) is the assumption, now well founded, that the albumin concentration ratio is a valid parameter under normal and pathological conditions. One can also choose some other proteins as permeability markers, but for various practical reasons only albumin, ceruloplasmin and $\alpha_{2}$-macroglobulin have been successfully utilized. Certainly the albumin ratios can be compared with those of all immunoglobulin classes to detect a local antibody nroduction, but a complete barrier evaluation should include a criterion of "selectivity" $(24,25)$. The linear protein gradient (serum/cerebrospinal fluid concentration ratios versus hydrodynamic radii in a semilogarithmic scale) constructed with albumin and $\alpha_{2}$-macroglobulin (26) can be extended into the size range of IgM and $\beta$ lipoprotein in cases with barrier disturbances (fig. 3).

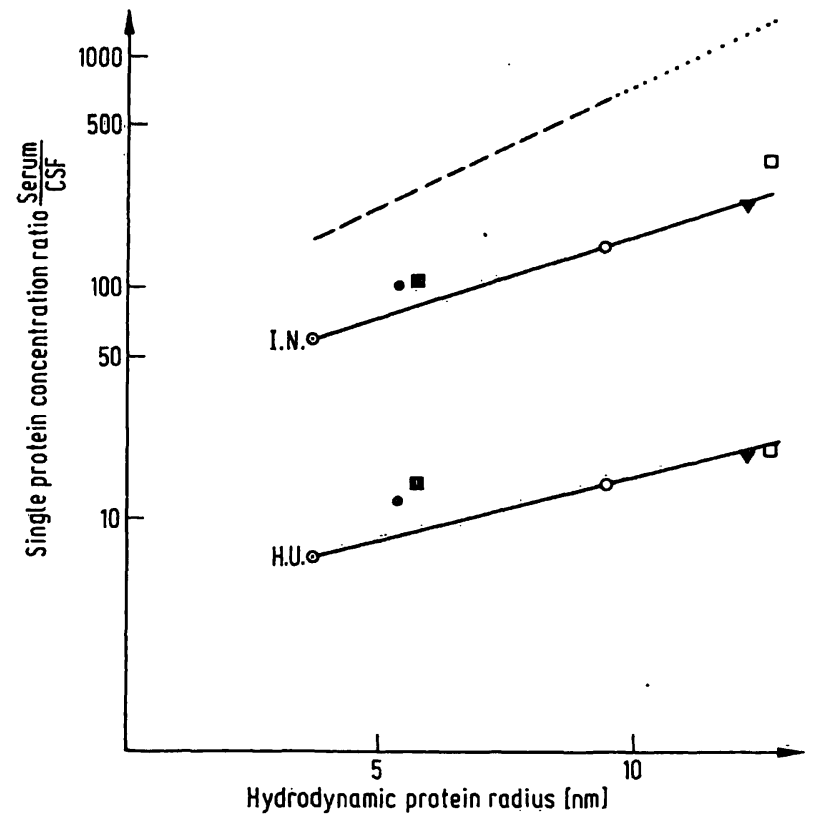

Fig. 3. Two examples of a disturbed blood-cerebrospinal fluid barrier:

Moderate barrier disturbance in patient I. N. suffering from viral meningitis, initial stage and barrier breakdown in patient $\dot{H}$. U. with pneumococcal meningitis. The broken line represents the normal protein gradient between the serum/cerebrospinal fluid ratios of albumin and $\alpha_{2}$-macroglobulin; its further extension not yet established in normal cases is drawn as a dotted line. In these cases the serum/cerebrospinal fluid ratios of albumin $(\odot, r=3.58 \mathrm{~nm})$, IgG $(\bullet, r=5.34 \mathrm{~nm})$, IgA $(\square, r=5.68 \mathrm{~nm}), \operatorname{IgM}(\nabla, r=12.1 \mathrm{~nm}), \alpha_{2}$-macroglobulin $(0, \mathrm{r}=9.35 \mathrm{~nm})$ and $\beta$-lipoprotein $(\mathrm{a}, \mathrm{r}=12.4 \mathrm{~nm})$ concentration were determined.

As the concentration ratios of cerebrospinal fluid proteins (a local synthesis of immunoglobulins excluded) only depends on the actual barrier state, the establishment of normal absolute values is of rather limited significance. To avoid misinterpretations, their content in cerebrospinal fluid can only be evaluated in reference to their serum counterparts. One female with a normal barrier condition showed a cerebrospinal fluid IgA level of $24 \mathrm{mg} / \mathrm{l}$, which was the result of an extremely elevated serum level due to an IgA myeloma. The serum/cerebrospinal fluid IgA ratio in this case had remained in the normal range.

Under routine conditions the determination of the serum/ cerebrospinal fluid ratios of both albumin and IgG might be sufficient. But in all inflammatory disorders the additional measurement of the serum/cerebrospinal fluid ratios of $\operatorname{IgA}$ and $\operatorname{IgM}$ is recommended, since an isolated synthesis of these immunoglobulins may occur.

\section{Acknowledgement}

The technical assistance of Mrs. Annerose Remy and Mr. M. Nekic is thankfully appreciated. 


\section{References}

1. Schliep, G., Rapić, N. \& Felgenhauer, K. (1974), this J. 12, 367-369.

2. Laurell, C.-B. (1972), Scand. J. Clin. Lab. Invest. 29, suppl. 124, 21-37.

3. Schliep, G. \& Felgenhauer, K. (1978), J. Neurol. 218, 77-96.

4. Lowry, O. H., Rosebrough, N. J., Farr, A. L. \& Randall, R. J. (1951), J. Biol. Chem. 193, 265-275.

5. Sieber, A. (1977), Laboratoriumsblätter 27, 109-118.

6. Lizana, J. \& Hellsing, K. (1974), Clin. Chem. 20, 415-420.

7. Munster, van P. J. J., Hoelen, G. E. J. M., Samwel-Mantingh, M. \& Holtman-van Meurs, M. (1977), Clin. Chim. Acta 76, 377-388.

8. Felgenhauer, K., Schliep. G. \& Rapić, N. (1975), in: Protides of the Biological Fluids (H..Peeters, ed.), Pergamon Press, Oxford - New York - Toronto - Sydney - Paris - Frankfurt, Vol. 23, 481-487.

9. Mancini, G., Carbonara, A. O. \& Heremans, J. F. (1965), Immunochemistry 2, 235-254.

10. Sieber, A. \& Gross, J. (1976), Laboratoriumsblätter 26, 117-123.

11. Pflughaupt, K. W. (1977), Symposium „Pathologie der Liquorräume", Dtsch. Ges. Neurol. Würzburg.

12. Pflughaupt, K. W., Sieber, A. \& Hackenberg, S. (1978), Laboratoriumsblätter $28,37-41$.

13. Conrad, A., Schürmann, J., Kreutz, F. H. \& Sieber, A. (1978), this J. 16, 299-305.
14. Bjerrum, O. J., Ingild, A., Løwenstein, H. \& Weeke, B. (1973), in: A Manual of Quantitative Immunoelectrophoresis. Methods and Applications Axelsen, N. H., Kr $\phi 11$, J. \& Weeke, B. (eds.) Universitetsforlaget Oslo, 145-148.

15. Weeke, B. (1968), Scand. J. Clin. Lab. Invest. 22, 107-111. 16. Hirsch-Marie, H. (1970), Bull. Soc. Chim. Biol. (Paris) 52, 631-639.

17. Richterich, R. (1971) in: Klinische Chemie, 3. Aufl. Karger, Basel, 126-152.

18. Killingworth, L. M. \& Savory, J. (1973), Clin. Chem. 19, 403-407.

19. Ritchie, R. F., Alper, C. A., Graves, J., Pearson, N. \& Larson, C. (1973), Amer. J. Clin. Pathol. 59, 151-159.

20. Shenkin, A., Morrison, B. \& Robertson, D. A. (1977), Ann Clin. Biochem. 14, 163-170.

21. Delpech, B. \& Lichtblau, E. (1972), Clin. Chim. Acta 37, 15-23.

22. Ganrot, K. \& Laurell, C.-B. (1974), Clin. Chem. 20, 571573.

23. Eickhoff, K., Wikström, J., Poser, S. \& Bauer, H. (1977), J. Neurol. 214, 207-215.

24. Burnett, D., Wood, S. M. \& Bradwell, A. R. (1976), Biochim. Biophys. Acta 427, 231-237.

25. Felgenhauer, K. \& Renner, E. (1977), Ann. Clin. Biochem. $14,100-104$.

26. Felgenhauer, K., Schliep, G. \& Rapić, N. (1976), J. Neurol. Sci. 30, 113-128.
Dr. med. G. Schliep Universitäts-Nervenklinik Köln Joseph-Stelzmann-Str. 9 5000 Köln 41 